\title{
The Role of University-Based Entrepreneurship Ecosystems in Facing the Challenges of the Industrial Revolution 4.0
}

\author{
Mona Novita*, Ahmad Husein Ritonga, Jalaludin Jalaludin \\ Islamic Education Management \\ UIN Sulthan Thaha Saifuddin Jambi \\ Jambi, Indonesia \\ *novitamona58@yahoo.com, jalaludinuinjambi@gmail.com
}

\begin{abstract}
The deliberation underlying this research was the launching of the Making Indonesia 4.0 by President Joko Widodo as a roadmap for entering the IR 4.0. In the university environment, there is a growing thought about various strategies in preparing students for the 4IR, such as dynamism, diversity of developed programs and the practices of the management, which are being applied at Padang State University (UNP). This research aims to explore the role of University-Based Entrepreneurship Ecosystems (UBEE) in UNP in getting millennial generations ready for the IR 4.0. The research applies the descriptive qualitative method and case study method. The result of the research concludes that UNP possesses the environment of technopreneurship in carrying out an identity as UBEE. Besides that, eight other strategies applied by the universities to face the 4IR: (1) university vision that leads to student entrepreneurship development, (2) create an academic community that have perspective as entrepreneur, (3) employ link and match strategy with the government and industry, (4) implement entrepreneurship programs both held by universities and Kemenristekdikti, (5) commit to the continuous program in long period, (6) commit to large financial resources, (7) commit to continuous innovation of curriculum, and (8) organize the infrastructures with the institution and entrepreneurial programs.
\end{abstract}

\section{Keywords: UBEE, 4IR, Padang State University}

\section{INTRODUCTION}

These days, the excellency in teaching and learning as well as the excellency in research for tertiary education graduates cannot guarantee the graduates' excellency in global competition. It needs a specific skill that is aligned with current employment needs. Specific expertise must be excellent in innovation, including students of Padang State University (UNP) graduates. If not, the University graduates will be left behind and eliminated. Moreover, at this time the world has entered a new era, namely the Industrial Revolution Era 4.0 (4IR) [1]. 4IR is currently a big trend and a major concern of the world, including in Indonesia.

The era which brought up the phenomenon of disruption demands the world of tertiary institutions to also adjust. The breadth and depth of the challenges of this change also signify a transformation throughout the production, management and governance systems [2]. So, it is not wrong if Alvin Toffler said that the rapid changes that occur today are changes that can make a surprise or Future Shock [3]. President Joko Widodo seems to race against other countries to launch Making Indonesia 4.0 [4]. In order to prepare competent human resources in the future in facing the 4IR era, every citizen needs to have digital literacy capabilities as stated by Motyl et al in the journal "The Effectiveness of Islamic Religious Education in the Universities: The Effects on the Students' Characters in the Era of Industry 4.0 ". Indonesia must be able to respond quickly and adaptively to be able to compete with other developed countries [5]. So that at present, there are three new literacies that must be had to face the 4IR as stated by the Minister of Research in Higher Education Technology, Prof. Mohamad Nasir, namely "Data Literacy", "Technology Literacy" and "Human Literacy". Undergraduate and student graduates must master: (i) Skills in leadership and teamwork, (ii) Ability to adapt to new technologies and global challenges (Cultural Agility), and (iii) have the ability to entrepreneurship [6]. Higher education as an organization is inseparable from the need for good leadership and management. Nancy W. Gleason stated that universities in the 4IR era were a place to think about creative ways to work so that universities were an ideal entrepreneurship ecosystem [7]. In line with Gleason, Aleksi also stated that the key actors in the entrepreneurial ecosystem are universities aside from entrepreneurs, investors, large companies and public authorities [8].

\section{RESEARCH METHOD}

The social situation in this study was conducted at UNP which is located at Jalan Prof. Dr. Hamka, Kelurahan Air Tawar Barat, Padang Utara District, Padang City, West Sumatra Province. The research subjects taken in this study were: (1) UNP Chancellor, (2) UNP Vice Chancellor III, (3) Head of Technical Implementation Unit Career Development and Entrepreneurship UNP, (4) Coordinator of Entrepreneurship, (5) Chairperson of the Student Activity Unit in Career and Entrepreneurship Development, (6) Chairperson 
- UNP continues to make technological innovations that support the learning and reform of higher education bureaucracy. The initial step taken by UNP is through the development of innovation-based institutions by facilitating laboratories (Industrial Laboratories in the Faculty of Engineering, Business Laboratories (banking and taxation) at the Faculty of Economics, Food and Fashion Laboratory at the Faculty of Tourism, Remote Sensing Technology Laboratory at the Faculty of Social Sciences, as well as the Language Laboratory at the Faculty of Languages and Arts), industrial workshops and workshop rooms for industry, entrepreneurship, and business [9].

2) Think and act strategically: The seriousness of the leadership of UNP and the entire academic community in preparing for the challenge of the presence of 4IR which is loaded with advanced technology can be seen from the following facts:

- UNP is conducting curriculum alignments in each study program with the business and industry climate in the face of the dynamics of the Indonesian Revolution 4.0 and the spirit of entrepreneurship.

- UNP applies a joint curriculum, joint degree and double degree for study programs that have International classes and are funded by the Joint Curriculum Competition Grant. In 2019, UNP already has 15 study programs opening International Classes, which have been prepared since 2 years ago.

- Chancellors starting from the University and Faculty level always emphasize the four urgent competencies that UNP students must possess, namely Critical thinking and problem solving, Creativity and innovation, Communication, and Collaboration.

- Chancellors on several occasions such as opening UNP student graduation events, opening UNP External Monitoring and Evaluation activities, UNP New Lecturer Job Meetings, Entrepreneurship Workshops, Public Lectures and others always emphasize to students that students must think solidify that can provide solutions to problems that appears in the community.

- Frequently hold national, international seminars, workshops, training, training, public lectures with themes related to 4IR.

- Make a collaboration with industry players.

- Utilization of digital technology to spur productivity and competitiveness so that it becomes a Superior University through e-learning, e-research, e-library, estudent activity, and other programs.

- Optimizing data satisfaction through Big Data that can be used to maximize the implementation of the tri dharma of higher education. The concrete evidence that has been implemented by UNP is the integration of all academic and non-academic information at the UNP Information and Services Center.

- Increasing study programs related to the industrial revolution 4.0.

3) Provide proactive services:

- Currently UNP has implemented Blended Learning as an alternative in dealing with 4IR sophistication. Blended learning is learning that combines face-to-face and e-learning with six components namely, face-toface, independent learning, applications, tutorials, 
collaboration, and evaluation. Some Study Programs at UNP have implemented Blended Learning based learning.

- Changing technology-based curriculum content. In addition, the learning process currently being carried out by UNP is also in the form of optimizing multimedia development, including the utilization of online-based facilities and infrastructure.

- UNP has prepared itself as a virtual university in responding to the presence of 4IR in Higher Education education in collaboration with Telkom Indonesia incorporated company. So now, all UNP students can access information from the internet without limits wherever they are by using free WiFi.id while being a UNP student.

- UNP builds ICT infrastructure through cyber universities. UNP has made changes and leaps as a form of readiness as a Higher Education institution entering this era of disruption with the development of cyber universities.

- UNP has made massive improvements in terms of structure, infrastructure and superstructure in facing the needs and challenges of an increasingly competitive era.

- UNP builds an entrepreneurial spirit, generates entrepreneurial generation by providing complementary units and infrastructure facilities that support the enhancement of the entrepreneurial spirit of UNP students such as the creation the unit of a Career and Entrepreneurship Development and student cooperative.

\section{B. Entrepreneurship Program Developed by UNP as a University-Based Entrepreneurship Ecosystems to Face the 4IR Era}

As mentioned in the introduction to this paper, the prerequisite for UNP's success in facing Revolution 4.0 is that it must have and must refer to an entrepreneurial university. Given this concept, the UNP as a Higher Education Institution which today is a "Towards Entrepreneurial University" university have prepared various programs related to student entrepreneurship. Here, researchers only limit the explanation of programs made by UNP in the entrepreneurship category because they rely on the theory conveyed by Gleason that universities in the 4IR era are a place to think about creative ways to work so that universities are the ideal entrepreneurship ecosystem [7]. The Entrepreneurship Program run by UNP is regulated in the Indonesian Student Entrepreneurship Program Guide from the Director General of Learning and Student Affairs of the Ministry of Research and Technology in 2017 [10] namely (1) General Entrepreneurship Study (in the form of entrepreneurship clinics, business plan preparation workshops, entrepreneurship training), (2) Student Programs Entrepreneurship for startups and existing businesses in the fields of Technology and Creative Industries, Food / Culinary, Goods and Services, (3) Indonesian Student Business Competition with types: Food and beverage, services and trade, creative industries, technology and production / cultivation, (4) Indonesian Student Entrepreneurship competition with types of business exhibitions, business gatherings, national seminars and entrepreneurial workshops, KMI Award Contest.

\section{Management of UNP Leader in Developing Student Entrepreneurship as an Important Component in $4 I R$}

Key actors in the entrepreneurial ecosystem are universities other than entrepreneurs, investors, large companies and public authorities [8]. With the academic entrepreneur in him, a university leader can play a role in advancing education in their educational institutions or also as a facilitator, motivator and innovator for students and subordinates [11]. So, the themes of "leadership" and "entrepreneurship" are the themes that are always relevant and challenging to study. The role of university leaders in developing student entrepreneurship is a key factor in making various breakthroughs to be ready to face the work industry that is increasingly developing along with technological advances, and facing the industrial revolution 4.0. So, Universities are required to answer the challenges to face technological progress and competition in the world of work in the current era of globalization by developing student entrepreneurship. The eight management strategies of the UNP leadership in dealing with 4IR, namely:

1) Having a university vision that leads to the development of student entrepreneurship: Looking at the mission of the fifth and sixth points of UNP, namely "Enhancing local, national and international cooperation" and "Developing a foundation and implementing policies towards one of the international universities". Whereas the aim of UNP is "Producing graduates who are competitive and adaptive to changes in the global environment", "Producing graduates who are knowledgeable, skilled, professional, cultured, of tough character and" Produce research, scientific work, and innovative creative works "[12]. Based on UNP's mission and strategic objectives above, it is clearly seen that the implementation of UNP student entrepreneurship programs is one way to achieve the mission and goals set by the leadership. And this is very directly related to the preparation for facing 4IR.

2) Having an academic community that has a perspective as an entrepreneur: From the observations made by researchers for three months, it can be seen that all UNP academics starting from the Chancellor, Vice Chancellor, Deans, all UNP Lecturers and students highly describe the entrepreneur's perspective. For example, among students, they are very active in participating in entrepreneurship and up-todate activities with venture capital funding programs both organized by UNP itself and from ministries, government and industry. Likewise, with the Chancellor and other UNP leaders. One interesting example is that the Chancellor has given three years in a row giving rewards in the form of money to students, lecturers and deans who excel at UNP given every national education day. So that it is able to pump 
up enthusiasm and motivation to be more innovative and relative among all UNP academics.

3) Has a link and match with the government and industry: At present there are very many harmonious relations between UNP, government and industry. For examples are the cooperation of UNP with some incorporated companies: Semen Padang, Pegadaian, PLN, BRI, the West Sumatra Province Tourism and Creative Economy Office, Bank BTN, Bukit Asam, Bank Nagari, Dharma Andalas Training Center, Ministry of Religion Halal Product Guarantee Agency, Denpasar Industrial Training Center, Cooperatives, Palm Oil Business Services, Saintika Padang, Andalas Business Solutions, and the Indonesian Cooperative Council and many more.

4) Implement entrepreneurial programs both organized by the university and by the Ministry of Research, Technology and Technology: UNP is very active in implementing entrepreneurship programs both conducted by UNP itself and from the Ministry of Research, Technology and Higher Education. As stated in explanation 3.2 above.

5) Having a program commitment that is ongoing for a long time: UNP is very consistent with the programs that have been planned in order to develop and improve the competencies of UNP students in dealing with 4IR. Some examples include: the preservation of student entrepreneurship programs that have been carried out from 2007 to the present. Then there is the Student Creativity Program which has also been maintained for the past decade. And made the Entrepreneurship Course as a UNP Mandatory Course from 2016 to now.

6) Having a commitment with large financial resources: With the number of links and matches that have been made by UNP with government and industry as explained, UNP also indirectly gets a large financial source in helping the development of UNP in general and students in particular.

7) Have a commitment in continuing curriculum innovation: The seventh point is clearly observed in UNP in terms of innovation in entrepreneurship learning curriculum. From 2016 until now, UNP has revised 3 curriculum courses on Entrepreneurship Courses. UNP is very up-to-date in seeing the current situation needed by students and graduates, so that curriculum revisions continue to be made. Likewise, the overall learning curriculum at UNP is conducted in the form of blended learning.

8) Adjusting infrastructure with the institutions and entrepreneurship programs that are organized: In order to achieve all the vision, mission and strategic plans from year to year UNP continues to improve. Some examples are: UNP undertook massive improvements in terms of structure, infrastructure and superstructure in facing the needs and challenges of an increasingly competitive era. The steps taken by UNP are through the development of innovation-based institutions by facilitating laboratories (Industrial Laboratories in the Faculty of Engineering, Business Laboratories (banking and taxation) at the Faculty of Economics, Food and Fashion Laboratory at the Faculty of Tourism, Remote Sensing Technology Laboratory at the Faculty of Social Sciences, and the Language Laboratory at the Faculty of Languages and Arts), industrial workshops and workshop rooms for industry, entrepreneurship, and business.

\section{CONCLUSION}

The strategies undertaken by UNP in dealing with 4IR challenges are: The making of four policies, thinking and acting strategically, providing proactive services. While the entrepreneurship program developed by UNP to face the 4IR era are General Entrepreneurship Study, Student Entrepreneurship Program, Indonesian Student Business Competition and Indonesian Student Entrepreneurship Competition. The management of UNP in developing student entrepreneurship) as one of the important components in 4IR, namely: Having a university vision that leads to the development of student entrepreneurship, Having an academic community that has a view as an entrepreneur, Having links and matches with government and industry Implementing good entrepreneurship programs held by the university or from the Ministry of Research, Technology and Higher Education, has a commitment of ongoing programs in a long time, has a commitment with great financial resources, has a commitment to continue curriculum innovation and adjusts infrastructure with institutions and entrepreneurship programs that are held right.

\section{REFERENCES}

[1] S. Priatmoko, "Strengthening the Existence of Islamic Education in Era 4.0" Ta'lim J. Stud. Educator Islam I 2. 2018

[2] M. Xu, J.M. David, S.H. Kim, "The Fourth Industrial Revolution: Opportunities and Challenges", Int. J. Financ. Res. 9 91. 2018

[3] U. Suharsaputra, Higher Education Management: Strategies for Facing Change ed Nurul Falah Atif (Bandung: PT Refika Aditama). 2015.

[4] A.N.B. Messepe, Making Indonesia 4.0 Our New Round of Industry Res. Gate 1. 2018.

[5] C. Anwar, A. Saregar, U. Hasanah, W Widayanti, "The Effectiveness of Islamic Religious Education in the Universities: The Effects on the Students' Characters in the Era of Industry 4.0" Tadris J. Kegur. and Tarb Science. 3 78. 2018.

[6] M. Nasir, "Indonesia Welcomes the 4th Industrial Revolution in the 2018, World Education Forum of the Ministry". Research, Tech. and Higher Education of Republic Indonesia. 2018.

[7] N.W. Gleason, Higher Education in the Era of the Fourth Industrial Revolution (Singapore: Springer Nature Singapore Pte Ltd). 2018.

[8] A. Aaltonen, Factors Shaping Entrepreneurial Ecosystems and the Rise of Entrepreneurship: A View from Top Management Journals. Demos Helsinki Associate. 2016.

[9] 201P UNP Public Relations Rector Prof. Ganefri: Facing the Industrial Revolution 4.0; UNP Curriculum More Competitive ump.ac.id

[10] 2017 Director General of Learning and Student Affairs Indonesian Student Entrepreneurship Program Guide Indonesian Student Entrepreneurship Program Guide (Jakarta: Ministry of Research, Technology and Higher Education)

[11] A.J. Djohan, 5 Pillars of Leadership in the 21st Century ed S Dr. Drg. Rosihan Adhani, MS (Malang: Media Nusa Creative). 2016.

[12] Ganefri, UNP 2018 Performance Report (Padang). 2018. 